\title{
Aspartate metabolism in Mycobacterium avium grown in host tissue and axenically and in Mycobacterium leprae
}

\author{
Venkataraman Sritharan, $\dagger$ Paul R. Wheeler* and Colin Ratledge \\ Department of Applied Biology, University of Hull, Hull HU6 7RX, UK
}

(Received 16 June 1989; revised 27 September 1989; accepted 9 October 1989)

\begin{abstract}
Aspartokinase activity was detected in extracts from Mycobacterium leprae (recovered from armadillo liver) and in Mycobacterium avium grown axenically and in vivo. Homoserine dehydrogenase activity was only detected in $M$. leprae and in M. avium grown axenically. Activities, when detected, were 50 to $70 \%$ lower in M. leprae or M. avium grown in vivo than in axenically grown $M$. avium. In these two pathogenic mycobacteria, aspartokinase and homoserine dehydrogenase are subject to feedback inhibition by methionine - an additional regulator over those observed for the enzymes from Mycobacterium smegmatis. Intact mycobacterium incorporated carbon from [U- ${ }^{4}$ Claspartate into the aspartate family of amino acids (threonine, isoleucine, methionine and lysine) though the rate of incorporation in $M$. avium grown in vivo was about half that in $M$. avium grown axenically.
\end{abstract}

\section{Introduction}

In order to grow and divide intracellular bacteria must, perforce, obtain their nutrients from the host cells inside which they reside. Asparagine, glutamate, aspartate and various other amino acids and metabolic precursors and intermediates are available in host tissues in significant quantities and various micro-organisms, including mycobacteria, can accumulate these substances to concentrations many times higher than in the environment (see Holden, 1962; Sritharan et al., 1987) and thus could use them directly rather than having to synthesize them $d e$ novo. This certainly seems to be the case with mycobacteria growing in vivo, which can assimilate and utilize exogenous fatty acids (Wheeler \& Ratledge, 1988) and nucleotides (Wheeler, 1987, 1989) the key enzymes involved in the biosynthesis of these compounds being depressed simultaneously.

Asparagine is a preferred source of nitrogen for many mycobacteria (Lyon et al., 1967). In M. smegmatis, the reason for this preference is probably the high activity of aspartokinase so that aspartate, derived from asparagine, can be rapidly utilized in various aspects of amino acid metabolism (Sritharan et al., 1989). Asparagine is also a carbon source, being linked to carbohydrate metabolism through its deamination to oxaloacetate. The objective of this study was to investigate the aspartate pathway in the obligate intracellular parasite $M$. leprae. As $M$. leprae has not been cultivated

† Present address: Department of Tropical Public Health, Harvard Medical School, 665 Huntington Avenue, Boston, MA 02115, USA. axenically, the regulation of the aspartate pathway was also studied in M. avium, a Mycobacterium which can be grown axenically and inside a mammalian host. Results obtained with $M$. avium were then used to interpret the findings with $M$. leprae.

\section{Methods}

Mycobacterial strains, growth and harvesting. M. avium CR1/69 (from the AFRC Institute for Research in Animal Diseases, Compton, Berkshire, UK) was grown axenically in glycerol/salts medium (Ratledge \& Hall, 1971) with asparagine as sole nitrogen source at $37^{\circ} \mathrm{C}$ in $100 \mathrm{ml}$ medium shaken $(200$ r.p.m.) in $250 \mathrm{ml}$ flasks. Suspensions were prepared for uptake studies by washing the bacteria three times in buffered Tween $80(0.1 \%$, w/v, Tween 80 in 1.5 mM-MES, pH 7.0).

For in vivo grown mycobacteria, $M$. leprae was grown in Ninebanded armadillos (Dasypus novemcinctus Linn.) and M. avium CR1/69 was grown in C57 Black mice (Wheeler, 1987). Bacteria were isolated from infected tissues by a method (World Health Organization, 1980) that yields highly purified suspensions and is applicable for metabolic studies on host-grown mycobacteria (Wheeler, 1984, 1987).

Uptake studies. Intact washed mycobacteria $\left(2 \times 10^{8}-5 \times 10^{9}\right)$ were added aseptically to the incubation medium described below and incubated at $37^{\circ} \mathrm{C}$ with orbital shaking ( $\sim 160$ r.p.m.) in siliconized screw-capped, glass vials for $4 \mathrm{~h}$ for $M$. avium and $24 \mathrm{~h}$ for $M$. leprae. The incubation mixture (Lyon et al., 1967), filter-sterilized, was routinely as follows: $100 \mu$ mol potassium phosphate buffer ( $\mathrm{pH} \mathrm{6.8)}$ ), $500 \mu \mathrm{mol}$ glycerol, $2 \mu \mathrm{mol} \mathrm{MgSO}_{4}$ and $100 \mathrm{U}$ penicillin $\mathrm{G}$ (for $>4 \mathrm{~h}$ incubations) in $1 \mathrm{ml}$. Changes in $\mathrm{pH}$ and energy source (replacing glycerol) for some incubations are indicated in the text. A single radioactive amino acid $(1 \mu \mathrm{mol} ; 18.5 \mathrm{kBq}$; diluted with unlabelled amino acid as required) was added to each incubation. The specific activities of the amino acids (obtained from Amersham) were as follows: $\mathrm{L}-\left[\mathrm{U}-{ }^{-14} \mathrm{C}\right]$ aspartic acid, $7400 \mathrm{GBq} \mathrm{mol}{ }^{-1} ; \mathrm{L}-\left[\right.$ methyl $\left./{ }^{-14} \mathrm{C}\right]$ methionine, $463 \mathrm{GBq} \mathrm{mol}{ }^{-1}$; and $\mathrm{L}-\left[\mathrm{U}^{-14} \mathrm{C}\right] \mathrm{lysine}, 5500 \mathrm{GBq} \mathrm{mol}^{-1}$. 
Controls contained bacteria killed with formalin $\left(4 \%, v / v\right.$, at $25^{\circ} \mathrm{C}$ for $18 \mathrm{~h}$ ), and their background activity was always subtracted when presenting uptake by live organisms.

Analysis of incubation products. At the end of each incubation, the samples were tested for contamination with fast-growing bacteria by plating $10 \mu \mathrm{l}$ samples on to nutrient agar plates. Further samples were taken to measure the following. (a) Assimilation by intact bacteria. The bacteria were collected on Whatman $\mathrm{GF} / \mathrm{C}$ filters under vacuum and washed four times at $4{ }^{\circ} \mathrm{C}$ with $15 \mathrm{ml}$ buffered Tween 80 each time. The filters (with the cells) were air-dried and radioactivity was determined as described below.

(b) Evolved ${ }^{14} \mathrm{CO}_{2} \cdot{ }^{14} \mathrm{CO}_{2}$ evolved during incubations was trapped in $400 \mu \mathrm{l} 0.5 \mathrm{M}-\mathrm{NaOH}$; the $\mathrm{NaOH}$ was contained in a separate vial from the incubation mixture inside the same sealed universal $(25 \mathrm{ml})$ vial.

(c) Incorporation into the amino acid pool. The labelled bacteria were washed three times in buffered Tween 80 by centrifugation and resuspension then extracted, first with boiling water $(200 \mu \mathrm{l}$ per $\mathrm{mg}$ dry wt of cells) for $30 \mathrm{~min}$ and then with the same volume of $60 \%(\mathrm{v} / \mathrm{v})$ ethanol at $4{ }^{\circ} \mathrm{C}$ for $60 \mathrm{~min}$. The two aqueous extracts were pooled, dried gradually at $50^{\circ} \mathrm{C}$ and then redissolved in $100 \mu \mathrm{l} 0.1 \mathrm{M}-\mathrm{HCl}$ for subsequent separation by TLC.

(d) Incorporation into proteins. The residue obtained after extracting the soluble pool was subjected to alkaline hydrolysis with barium hydroxide $\left(15 \mathrm{mg}\right.$ per $\mathrm{mg}$ dry wt of cells) at $120^{\circ} \mathrm{C}$ for $24 \mathrm{~h}$ in sealed ampoules. The $\mathrm{pH}$ of the hydrolysate was adjusted to 6.0 with $1 \mathrm{M}$ $\mathrm{H}_{2} \mathrm{SO}_{4}$ and the hydrolysate heated at $100^{\circ} \mathrm{C}$ for $5 \mathrm{~min}$ in a boiling water-bath. The contents were centrifuged and the precipitate was washed once with distilled water. The supernatant and the washing were pooled and dried at $50^{\circ} \mathrm{C}$. The residue was redissolved in $100 \mu \mathrm{l}$ $0 \cdot 1 \mathrm{M}-\mathrm{HCl}$ for further analysis.

Separation and identification of amino acids. Samples $(10 \mu \mathrm{l})$ of the pool extract or alkaline hydrolysate were separated by two-dimensional TLC using Silica Gel G plates (Uniplate; Analtech). The plates were developed first with butanol/glacial acetic acid/water $(4: 1: 1$, by vol.) dried, and then developed with ethanol/sp.gr. $0 \cdot 880 \mathrm{NH}_{4} \mathrm{OH}(77: 23$, $\mathrm{v} / \mathrm{v})$ in the second dimension. The amino acids were identified by spraying plates with fluorescamine (Roche; $30 \mathrm{mg}$ dissolved in $100 \mathrm{ml}$ $10 \%, \mathrm{v} / \mathrm{v}$, triethanolamine in acetone) and visualized under UV light (Imai et al., 1974). The areas corresponding to particular amino acids were marked, scraped off the plates and their radioactivity determined.

Determination of radioactivity. $\mathrm{NaOH}$ including trapped ${ }^{14} \mathrm{CO}_{2}$ was mixed with Bray's scintillant. Intact cells and their fractions were first solubilized with $0.5 \mathrm{ml}$ Soluene 100 (Packard) at $50^{\circ} \mathrm{C}$ for $60 \mathrm{~min}$, neutralized with $50 \mu \mathrm{l}$ glacial acetic acid and mixed with Bray's scintillant. Scrapings of silica gel from TLC plates were first mixed with about $1 \mathrm{~g}$ Cabosil (Koch-Light) and then with Bray's scintillant. The radioactivity was determined by liquid-scintillation counting.

Preparation of cell-free extracts. Cell-free extracts, usually desalted, were prepared as described previously (Sritharan et al., 1987). Protein was estimated by the method of Bradford (1976).

Enzyme assays. Aspartokinase (EC 2.7.2.4; ATP: L-aspartate 4phosphotransferase) was assayed by the $\mathrm{FeCl}_{3}$ method (Stadtman, 1961) except that the final colour was developed with $3 \mathrm{ml} \mathrm{FeCl} 3(5 \%$, $\mathrm{w} / \mathrm{v}$ ) instead of $1.5 \mathrm{ml}$ in the published method. This modification obviated the need for centrifugation. $A_{520}$ values were determined and enzyme activity was calculated using $\varepsilon=0.35 \mathrm{mM} \mathrm{cm}^{-1}$. L-Aspartate was routinely included at $20 \mathrm{mM}$, and only varied - between $12.5 \mathrm{mM}$ and $200 \mathrm{mM}$ - when $K_{\mathrm{m}}$ values for aspartate were determined; ATP was routinely included at $20 \mathrm{mM}$, and only varied - between $5 \mathrm{mM}$ and $50 \mathrm{~mm}$ - when $K_{\mathrm{m}}$ values for ATP were determined. Specific activity of the enzyme is expressed as $\mu \mathrm{mol}$ aspartohydroxamate formed $\mathrm{min}^{-1}$ (mg protein) $)^{-1}$
Homoserine dehydrogenase (EC 1.1.1.3; L-homoserine : NAD(P) ${ }^{+}$ oxidoreductase) was assayed by the standard method (Datta \& Gest, 1970) which we used previously (Sritharan et al., 1987). DL-Homoserine was routinely included at $20 \mathrm{mM}$ and only varied - between $10 \mathrm{mM}$ and $70 \mathrm{mM}$ - when $K_{\mathrm{m}}$ values for homoserine were determined; NADP was routinely included at $4 \mathrm{mM}$ and only varied - between $0.15 \mathrm{~mm}$ and 4 mM - when $K_{\mathrm{m}}$ values for NADP were determined. Specific activity of the enzyme is expressed as $\mu$ mol NADH produced (mg protein) $)^{-1}$ $\min ^{-1}$

\section{Results}

\section{Aspartate metabolism in intact $M$. leprae}

Uptake of $\mathrm{L}-\left[\mathrm{U}-{ }^{1+} \mathrm{C}\right]$ aspartic acid was more rapid at $\mathrm{pH}$ 6.8 and 8 than at pH 5.5 or 7.2 (Table 1). As aspartate transport is an energy-dependent process in mycobacteria (Israeli et al., 1977), various compounds were tested as energy source for this process in $M$. leprae at $\mathrm{pH} 5 \cdot 5$, as this $\mathrm{pH}$ value is close to the $\mathrm{pH}$ inside the macrophage in which $M$. leprae resides (Lowrie, 1983). Aspartate uptake was most rapid in the presence of pyruvate, though differences were not significant $(P>0.05$; Student's $t$ test), and slowest in the presence of glucose $(P<0.05)$ (Table 1). Very little radioactivity was incorporated into amino acids of the aspartate family (threonine, isoleucine, methionine and lysine) from $\left[\mathrm{U}-{ }^{14} \mathrm{C}\right]$ aspartate (Table 2), totalling $6 \mathrm{~Bq}$ per $10^{9}$ organisms in $24 \mathrm{~h}$. The reason for the failure to detect any incorporation into isoleucine may be that the limit of detection is about $0.5 \%$ of the radioactivity in the pool, only a half to a third of that detected in threonine and asparagine. Only $38 \%$ of the incorporated radioactivity was recovered in the amino acids listed in Table 2; the remainder was not sought, but could be in carboxylic acids derived from deamination of the amino acid.

\section{Table 1. Effect of $p H$ and energy source on aspartate uptake by $M$. leprae}

Intact $M$. leprae organisms $\left(\sim 10^{9}\right)$ were incubated with $18.5 \mathrm{MBq}$ [U-1 $\left.{ }^{14} \mathrm{C}\right]$ aspartate, buffer, $\mathrm{MgSO}_{4}$ and penicillin as in Methods, together with one energy source $(10 \mu \mathrm{mol})$ in $1 \mathrm{ml}$. Incubation mixtures were shaken at $37^{\circ} \mathrm{C}$ for $24 \mathrm{~h}$. Values for aspartate uptake are Bq per $10^{9} \mathrm{M}$. leprae organisms in $24 \mathrm{~h}, \pm$ SEM. Six incubations were done using duplicates with three separate suspensions of $M$. leprae.

\begin{tabular}{lcc}
\hline Energy source & $\mathrm{pH}$ & $\begin{array}{c}\text { Uptake of }{ }^{14} \mathrm{C} \\
\text { from aspartate }\end{array}$ \\
\hline Glycerol & $5 \cdot 5$ & $43 \pm 13$ \\
& $6 \cdot 8$ & $105 \pm 10$ \\
& $7 \cdot 2$ & $72 \pm 13$ \\
Glucose & $8 \cdot 0$ & $102 \pm 20$ \\
Succinate & $5 \cdot 5$ & $19 \pm 5$ \\
Pyruvate & $5 \cdot 5$ & $35 \pm 13$ \\
\hline \hline
\end{tabular}


Table 2. Distribution of label from $\left[U-{ }^{14} \mathrm{C}\right]$ aspartate into other amino acids of the aspartate family in $M$. leprae and $M$. avium

Intact $M$. leprae organisms $\left(\sim 10^{9}\right)$ were incubated with $\left[\mathrm{U}-{ }^{14} \mathrm{C}\right]$ aspartic acid under the standard conditions ( $\mathrm{pH} 6.8$, with glycerol) described in Methods and shaken at $37^{\circ} \mathrm{C}$, for $4 \mathrm{~h}$ in the case of $M$. avium and $24 \mathrm{~h}$ in the case of $M$. leprae. Amino acids of the soluble pool were extracted and analysed as in Methods. 'Aspartate taken up' includes carbon assimilation and metabolism to $\mathrm{CO}_{2}$. Eight incubations were done for $M$. avium grown axenically, six for $M$. avium grown in mice, and four for $M$. leprae obtained from armadillo tissue. Values are expressed as a percentage of the radioactivity associated with the extractable pool of amino acids, or as total radioactivity taken up or in pool amino acids.

\begin{tabular}{|c|c|c|c|}
\hline \multirow[b]{2}{*}{$\begin{array}{l}\text { Amino } \\
\text { acid }\end{array}$} & \multicolumn{3}{|c|}{ Percentage radioactivity in each amino acid, \pm SEM } \\
\hline & M. leprae & $\begin{array}{l}\text { M. avium grown } \\
\text { axenically }\end{array}$ & $\begin{array}{c}\text { M. avium grown } \\
\text { in C57 Black mice }\end{array}$ \\
\hline Aspartate & $24 \pm 5$ & $71 \pm 3$ & $75 \pm 4$ \\
\hline Asparagine & $1 \cdot 7 \pm 0 \cdot 7$ & $4 \pm 0 \cdot 7$ & $1 \cdot 5 \pm 0 \cdot 3$ \\
\hline Threonine & $1 \cdot 0 \pm 0.6$ & $6 \pm 2$ & $0.8 \pm 0.2$ \\
\hline Isoleucine & $0 \pm 1 \cdot 0$ & $1 \cdot 2 \pm 0.9$ & $1.8 \pm 0.4$ \\
\hline Methionine & $5 \cdot 0 \pm 3 \cdot 0$ & $1.5 \pm 0.6$ & $0 \cdot 6 \pm 0 \cdot 1$ \\
\hline Lysine & $5 \cdot 7 \pm 2 \cdot 6$ & $4 \pm 1$ & $2 \cdot 4 \pm 0.6$ \\
\hline $\begin{array}{l}\text { Total radioactivity } \\
\text { in above amino } \\
\text { acids }(\%)\end{array}$ & 37 & 92 & 82 \\
\hline $\begin{array}{l}\text { Pool amino acids } \\
\text { (100\% radioactivity; } \\
\text { Bq per } 10^{9} \text { bacteria) }\end{array}$ & $45 \pm 6$ & $87 \pm 3$ & $98 \pm 8$ \\
\hline $\begin{array}{l}\text { Aspartate taken up } \\
\text { (Bq per } 10^{9} \text { bacteria) }\end{array}$ & $105 \pm 10$ & $225 \pm 7$ & $155 \pm 23$ \\
\hline
\end{tabular}

Table 3. Uptake of $\left[U-{ }^{14} C\right] l y$ sine and $[$ methyl$\left.{ }^{14} \mathrm{C}\right]$ methionine by $M$. avium

Intact $M$. avium organisms $\left(\sim 10^{9}\right)$ were incubated with buffer and $\mathrm{MgSO}_{4}$ as in Methods. Values for uptake are Bq per $10^{9} \mathrm{M}$. avium in $4 \mathrm{~h}, \pm$ SEM. Four incubations were done, all duplicates with two separate suspensions of $M$. avium.

\begin{tabular}{lcc}
\hline \hline & \multicolumn{2}{c}{ Amino acid uptake } \\
\cline { 2 - 3 } Growth in: & {$\left[{ }^{14} \mathrm{C}\right]$ Lysine } & {$\left[{ }^{14} \mathrm{C}\right]$ Methionine } \\
\hline Glycerol + asparagine & & \\
medium & $36 \pm 1$ & $28 \pm 3$ \\
C57 Black mice & $105 \pm 11$ & $108 \pm 1$ \\
\hline
\end{tabular}

\section{Aspartate metabolism in $M$. avium grown in vivo and axenically}

M. avium grown in vivo took up less $\left[\mathrm{U}-{ }^{14} \mathrm{C}\right]$ aspartic acid than $M$. avium grown axenically. This reflects lower rates of both protein synthesis and evolution of $\mathrm{CO}_{2}$ from aspartate in $M$. avium grown in vivo (Sritharan, 1988), but not the appearance of radioactivity in the amino acid pool (Table 2). However, the total radioactivity in the amino acids of the aspartate family was lower $-6 \mathrm{~Bq}$ per $10^{9}$ bacteria in $4 \mathrm{~h}-$ in $M$. avium grown in vivo than in $M$. avium grown axenically, when it was $11 \mathrm{~Bq}$ per $10^{9}$ bacteria in $4 \mathrm{~h}$ (calculated from Table 2). In contrast, $M$. avium grown in vivo showed significantly higher (three to four times) uptake of exogenously supplied L-[methyl$\left.{ }^{14} \mathrm{C}\right]$ methionine and $\mathrm{L}-\left[\mathrm{U}-{ }^{14} \mathrm{C}\right]$ lysine (i.e. two of the amino acids synthesized from aspartate) than $M$. avium grown axenically (Table 3 ).

\section{Aspartokinase in extracts of $M$. avium and M. leprae}

Aspartokinase was present at a specific activity of 0.33 units (mg protein $)^{-1}$ in $M$. avium grown axenically. The enzyme had an apparent $K_{\mathrm{m}}$ of $29 \mathrm{~mm}$ for aspartic acid and $19 \mathrm{~mm}$ for ATP. Methionine was the major feedback inhibitor of this enzyme (Table 4) but a combination of two, or all three, of lysine, methionine and threonine (all at $2 \mathrm{mM}$ ) gave 40 to $43 \%$ inhibition, the maximum with any combination of two or three amino acids.

The specific activity of aspartokinase in $M$. avium recovered after growth in mice was about a quarter of the specific activity of aspartokinase in axenically grown $M$. avium (Table 4). Perhaps more significant was that this 
Table 4. Inhibition of aspartokinase in M. avium and M. leprae

Aspartokinase activity was assayed at $\mathrm{pH} 9$ and $30^{\circ} \mathrm{C}$ in cell-free extracts as in Methods; the assay mixture contained $20 \mathrm{~mm}$-aspartate and $20 \mathrm{~mm}$-ATP. Values are means from four assays done with extracts prepared from three isolates of each source. The range of percentage inhibition was the mean $\pm 5 \%$. Values for $100 \%$ activity (with no inhibitor) were $0.33 \pm 0.036$ units (mg protein) ${ }^{-1}$ for $\boldsymbol{M}$. avium grown axenically in asparagine medium, $0.085 \pm 0.024$ for $M$. avium grown in C57 Black mice and $0.097 \pm 0.012$ for $M$. leprae (variance term: SEM).

\begin{tabular}{lccccc}
\hline \hline & $\begin{array}{c}\text { Inhibitor } \\
\text { concn. } \\
\text { Organism/source }\end{array}$ & \multicolumn{3}{c}{ Percentage inhibition of aspartokinase activity by: } \\
\cline { 3 - 6 } & L-Threonine & DL-Homoserine & L-Methionine & L-Lysine \\
\hline M. avium grown & 2 & 12 & 24 & 26 & 4 \\
in asparagine & 5 & 44 & 42 & 53 & 18 \\
medium & 10 & 50 & 50 & 54 & 58 \\
& 25 & 53 & 60 & 58 & 58 \\
& 50 & 58 & 68 & 60 & 60 \\
M. avium grown & 5 & 40 & 17 & 4 & 20 \\
in C57 Black & 10 & 43 & 40 & 10 & 24 \\
mice & 20 & 45 & 40 & 14 & 35 \\
$M$. leprae & 10 & 16 & 20 & 0 & 23 \\
isolated from & 20 & 60 & 62 & 17 & 24 \\
armadillo liver & 50 & 85 & 76 & 25 \\
\hline \hline
\end{tabular}

enzyme had a lower affinity for aspartate (apparent $K_{\mathrm{m}}$ $60 \mathrm{mM}$ ) and ATP (apparent $K_{\mathrm{m}} 26 \mathrm{mM}$ ) than the enzyme from in vivo grown cells and moreover, it was inhibited by threonine and homoserine while methionine had barely any inhibitory effect (Table 4).

Though aspartokinase activity was present in $M$. leprae at a specific activity of $\left.[0.097 \text { units (mg protein })^{-1}\right]$ which was comparable to that of $M$. avium also grown in vivo, it had affinities towards aspartate (apparent $K_{\mathrm{m}} 25$ $\mathrm{mM}$ ) and ATP (apparent $K_{\mathrm{m}} 20 \mathrm{mM}$ ) which were similar to those of the enzyme from $M$. avium grown axenically rather than in vivo. However, its inhibition by threonine and homoserine and not, or only weakly, by methionine or lysine was similar to inhibition of aspartokinase activity from $M$. avium grown in vivo.

During determinations of $K_{\mathrm{m}}$ values, individual values for reaction velocities varied no more than $7 \%$ from the regression line in the Lineweaver-Burk plots. Thus the apparent $K_{\mathrm{m}}$ values for ATP are similar, but the $K_{\mathrm{m}}$ for aspartate of $60 \mathrm{mM}$ for aspartokinase in $M$. avium grown in vivo appears distinct from the apparent $K_{\mathrm{m}}$ for aspartokinase in $M$. avium grown axenically and in $M$. leprae.

\section{Homoserine dehydrogenase in extracts of $M$. avium and M. leprae}

Cell-free extracts of $\boldsymbol{M}$. avium grown on asparagine medium contained homoserine dehydrogenase at a specific activity of 1.4 units (mg protein $)^{-1}$ with apparent
$K_{\mathrm{m}}$ values of $40 \mathrm{~mm}$ and $0.32 \mathrm{mM}$ for DL-homoserine and $\mathrm{NADP}^{+}$, respectively. Threonine and isoleucine inhibited the activity of this enzyme significantly while methionine or lysine had little effect (Table 5). Together at $1 \mathrm{~mm}$ each, threonine and isoleucine gave $60 \%$ inhibition of homoserine dehydrogenase activity from $M$. avium, a value greater than for either, individually, at $10 \mathrm{~mm}$ - this is concerted feedback inhibition (see TruffaBachi, 1973).

Homoserine dehydrogenase activity could not be detected in extracts of different isolates of $M$. avium grown in separate batches of mice. The limit of detection, using $8 \mathrm{mg}$ protein $\mathrm{ml}^{-1}$, was 0.00125 units (mg protein $)^{-1}$. However, extracts of $M$. leprae contained homoserine dehydrogenase at 0.72 units (mg protein $)^{-1}$, about half the activity which was present in axenically grown $M$. avium. Affinities for the substrates were also similar (apparent $K_{\mathrm{m}} 32 \mathrm{mM}$ and $0.15 \mathrm{~mm}$ for DLhomoserine and $\mathrm{NADP}^{+}$, respectively) to those of the enzyme from $M$. avium grown axenically. During determinations of $K_{\mathrm{m}}$ values individual values for reaction velocities varied from the regression lines in Lineweaver-Burk plots as follows: with DL-homoserine, no more than $3 \%$; with NADP, no more than $25 \%$. Methionine was the most potent inhibitor of homoserine dehydrogenase activity through threonine and isoleucine also had some inhibitory effect (Table 5). When the effect of these inhibitors was tested in different combinations (each at $5 \mathrm{~mm}$ ), the inhibition observed was additive. 
Table 5. Inhibition of homoserine dehydrogenase

Homoserine dehydrogenase was assayed at $\mathrm{pH} 9$ and $37^{\circ} \mathrm{C}$ in cell-free extracts as in Methods; the assay mixture contained $20 \mathrm{mM}$-DL-homoserine and $4 \mathrm{mM}$-NADP. Values are means from four assays done with extracts prepared from three different isolates. The range of percentage inhibition values was the mean $\pm 5 \%$. Values for $100 \%$ activity (with no inhibitor) were 1.4 units (mg protein $)^{-1}$ and 0.72 units (mg protein) ${ }^{-1}$ for $M$. avium grown on asparagine medium and $M$. leprae respectively.

\begin{tabular}{lccccc}
\hline \hline \multirow{2}{*}{$\begin{array}{c}\text { Organism/ } \\
\text { source }\end{array}$} & $\begin{array}{c}\text { Inhibitor } \\
\text { concn. } \\
(\mathrm{mM})\end{array}$ & \multicolumn{4}{c}{ Percentage inhibition of homoserine dehydrogenase activity } \\
\cline { 3 - 6 } & L-Threonine & L-Isoleucine & L-Methionine & L-Lysine \\
\hline M. avium grown & 2.5 & 20 & 15 & $\mathrm{~s}$ & $\mathrm{~S}$ \\
in asparagine & $5 \cdot 0$ & 26 & 20 & $\mathrm{~S}$ & $\mathrm{~S}$ \\
medium & 10.0 & 40 & 20 & 2 & $\mathrm{~S}$ \\
& 20.0 & 60 & 20 & 15 & $\mathrm{~S}$
\end{tabular}

\begin{tabular}{|c|c|c|c|c|c|}
\hline $\begin{array}{l}\text { M. avium grown } \\
\text { in C57 Black } \\
\text { mice }\end{array}$ & \multicolumn{5}{|c|}{ Activity not detectable } \\
\hline M. leprae & 5 & 40 & 60 & 70 & 4 \\
\hline $\begin{array}{l}\text { isolated from } \\
\text { armadillo liver }\end{array}$ & 10 & 50 & 65 & 85 & 5 \\
\hline
\end{tabular}

*s, Slight stimulation (upto $8 \%$ )

\section{Discussion}

Mycobacteria harvested from host tissue and incubated in a medium which did not support growth synthesized the aspartate family of amino acids more slowly than axenically grown mycobacteria incubated in the same medium. It was important to use a medium which did not support growth of $M$. avium to determine any differences between bacteria grown in vivo and in vitro, so that one explanation for any differences between metabolism in $M$. leprae and the cultivable mycobacterium could be ruled out, i.e. that $M$. leprae was not growing but $M$. avium was. Furthermore, even though mycobacteria harvested from host tissue are subject to a lengthy purification procedure they appear to be metabolically intact: activities such as incorporation of hypoxanthine into nucleic acids are detected at levels similar to those found in axenically grown mycobacteria (Wheeler, 1987); the ATP content of $M$. leprae is comparable with the ATP content of rapidly growing mycobacteria (reviewed in Barclay \& Wheeler, 1989); and in this study, uptake of lysine and methione - two of the aspartate family - was higher for host-grown $M$. avium than for axenically grown $M$. avium (Table 3). This final observation (Table 3 ) also suggests that the host-grown mycobacteria tend to scavenge amino acids of the aspartate family rather than synthesize them from aspartate.

The slow rate of biosynthesis of the aspartate family in host-grown mycobacteria, including $M$. leprae (Table 2) could be a result of repression or feedback inhibition of the pathway. The relatively low specific activities of the first two enzymes of the pathway - aspartokinase and homoserine dehydrogenase - provides evidence for repression, as these activities were detected in desalted extracts from mycobacteria, from which any endogenous feedback inhibitors would be removed. Repression of these two enzymes also occurs in the saprophytic $M$. smegmatis grown in the presence of the aspartate family of amino acids (Sritharan et al., 1989; see also Fig. 1). The failure to detect homoserine dehydrogenase activity at all in $M$. avium grown in vivo is somewhat puzzling. The finding that $M$. leprae incorporates 4 to $6 \%$ of ${ }^{14} \mathrm{C}$ from aspartate into methionine and lysine as against 0.5 to $2 \%$ in $M$. avium grown in vivo is consistent with the failure to detect the enzyme in $M$. avium grown in vivo, but its low activity in $M$. leprae. However, $M$. avium grown in vivo incorporates ${ }^{14} \mathrm{C}$ from aspartate into isoleucine, an activity which requires the participation of homoserine dehydrogenase.

Feedback inhibition of both aspartokinase (Table 4) and homoserine dehydrogenase (Table 5) provides a further mechanism for control of aspartate metabolism in $M$. leprae and $M$. avium. Differences in patterns of inhibition of aspartokinase activity between $M$. avium grown axenically and grown in vivo may be due to different proportions of isoenzymes being elaborated under different growth conditions, if each isoenzyme is affected as they are in $M$. smegmatis (Sritharan et al., 1989) by different amino acids. These results show the overall effect of inhibitors on aspartokinase activity. 


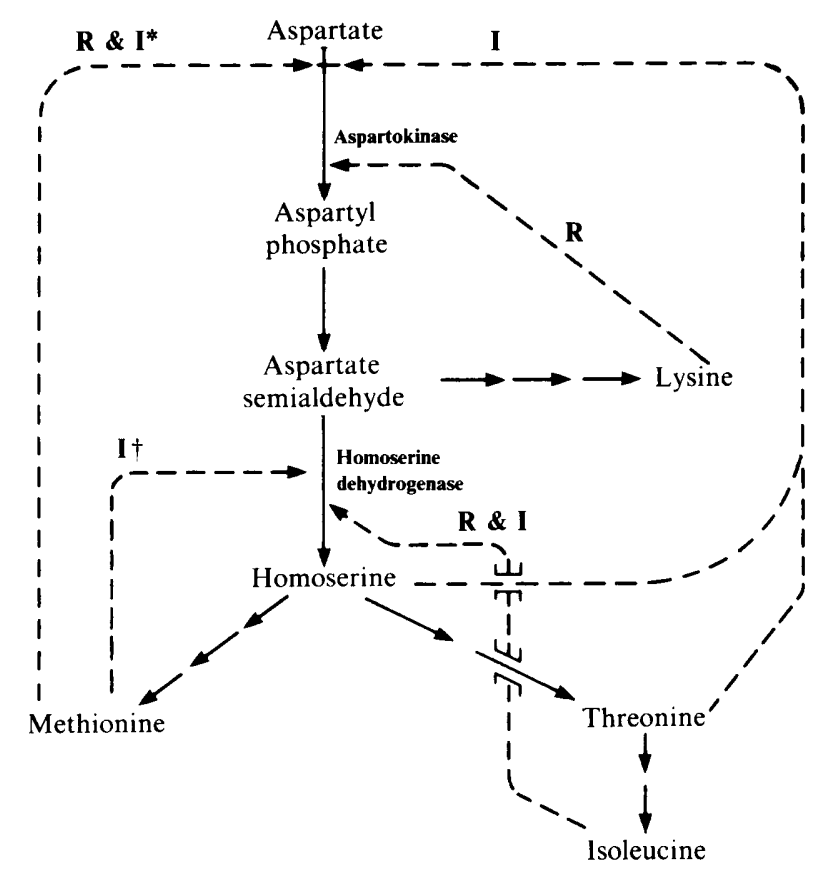

Fig. 1. Regulation of the aspartate pathway in mycobacteria. Feedback inhibition (I) and repression ( $\mathrm{R}$ ) of aspartokinase and homoserine dehydrogenase are shown in the scheme. $\rightarrow$, Pathway; $--\rightarrow$, regulatory effect.

* Inhibition by methionine of aspartokinase in $M$. avium (grown in vitro).

† Inhibition of homoserine dehydrogenase in $M$. leprae. Three aspartokinase isoenzymes occur in $M$. smegmatis.

Attempts to look for isoenzymes of aspartokinase in $M$. avium and $M$. leprae would require considerably greater amounts of bacteria, as demonstration of such isoenzymes would require their partial purification (Sritharan et al., 1989). The feedback inhibition may have affected the activities shown in Table 2, though this is speculative without knowing the pool sizes for various amino acids in these difficult-to-obtain mycobacteria. What is known is that mycobacteria can accumulate amino acids to concentrations several times higher than in the environment (Sritharan et al., 1987). This suggests that the inhibition effects, shown in Tables 4 and 5 , could occur in mycobacteria growing in vivo, as amino acids of the aspartate family are readily available within mammalian tissues. Pathogenic mycobacteria are clearly capable of scavenging these amino acids from the environment as shown in this work: exogenously supplied methionine and lysine as well as aspartate are incorporated by $\boldsymbol{M}$. avium grown in vivo (Table 3 ).

Aspartokinase and homoserine dehydrogenase in $M$. smegmatis were shown previously (Sritharan et al., 1989) to be subject to complex regulation, with all the products of amino acid biosynthesis via aspartate, the aspartate family of amino acids, being feedback inhibitors or repressors, or both, of one or both activities (see Fig. 1). Complex though the regulation was in $M$. smegmatis, additional control is shown here in $M$. avium, which exhibited feedback regulation of aspartokinase by methionine, and also in $M$. leprae in which homoserine dehydrogenase was strongly inhibited by methionine.

The additional complexities in the regulation of aspartate metabolism in the pathogenic mycobacteria, and differences between $M$. leprae and $M$. avium may reflect the greater problems of acquiring nutrients - in this case amino acids - which intracellular microbes encounter. Amino acids can be withheld from intracellular parasites by host cells in an attempt to achieve nutritional immunity (Byrne et al., 1986). In this context the complex pattern of regulation of the aspartate pathway (Fig. 1) - perhaps reflected in the ability of $M$. leprae preferentially to synthesize methionine and lysine but of host-grown $M$. avium preferentially to synthesize isoleucine (shown in Table 2) - may play a vital role in the nutrition of pathogenic mycobacteria.

V.S. was supported by the Commonwealth Scholarship Committee (UK) and P.R.W. thanks the UNDP/World Bank/WHO Special Programme for Research and Training in Tropical Diseases and LEPRA for financial support.

\section{References}

BARCLAY, R. \& WhEELER, P. R. (1989). Metabolism of mycobacteria in tissues. In The Biology of tine Mycobacteria, vol. 3, pp. 37-106. Edited by C. Ratledge, J. Stanford \& J. M. Grange. London: Academic Press.

BRADFORD, M. M. (1976). A rapid and sensitive method for the quantitation of protein utilising the principle of protein-dye binding. Analytical Biochemistry 72, 248-254.

ByrNe, G. I., LehmanN, L. K. \& LaNDRY, G. J. (1986). Induction of tryptophan catabolism in the mechanism for gamma-interferonmediated inhibition of intracellular Chlamydia psittari replication in T24 cells. Infection and Immunity 53, 347-351.

DatTA, P. \& Gest, H. (1970). Homoserine dehydrogenase. Methods in Enzymology 17A, 703-707.

HoLDEN, J. T. (1962). Transport and accumulation of amino acids by micro-organisms. In Amino Acid Pools: Distribution, Formation and Function of Free Amino Acids, pp. 566-594. Edited by J. T. Holden. Amsterdam: Elsevier.

IMAi, K., Bohlen, P., Stein, S. \& Udenfriend, S. (1974). Detection of fluorescamine labelled amino acids, peptides and other primary amines on thin layer chromatograms. Archives of Biochemistry and Biophysics 161, 161-163.

Israeli, E., Kalra, V. K. \& Brodie, A. F. (1977). Different binding sites for entry and exit of amino acids in whole cells of Mycobacterium phlei. Journal of Bacteriology 130, 729-735.

LOWRIE, D. B. (1983). Mononuclear phagocyte-mycobacterium interaction. In The Biology of the Mycobacteria, vol. 2, pp. 235-278. Edited by C. Ratledge \& J. Stanford. London: Academic Press.

Lyon, R. H., Rogers, P., Hall, W. M. \& Lichstein, H. C. C. (1967). Inducible glutamate transport in mycobacteria and its relation to glutamate oxidation. Journal of Bacteriology 94, 92-100.

RATLEDGE, C. (1982). Nutrition, growth and metabolism. In The Biology of the Mycobacteria, vol. 1, pp. 186-272. Edited by C. Ratledge \& J. Stanford. London: Academic Press. 
Ratledge, C. \& Hall, M. J. (1971). Influence of metal ions on the formation of mycobactin and salicylic acid in Mycobacterium smegmatis grown in static culture. Journal of Bacteriology 108, 312319.

SRITHARAN, V. (1988). Studies on amino acid metabolism in mycobacteria grown in vitro and in vivo. $\mathrm{PhD}$ thesis, University of Hull, UK.

Sritharan, V., Wheeler, P. R. \& Ratledge, C. (1987). Effect of homoserine on growth of Mycobacterium smegmatis: inhibition of glutamate transport by homoserine. Journal of General Microbiology 133, 2781-2785.

Sritharan, V., Wheeler, P. R. \& Ratledge, C. (1989). Metabolism of aspartate in Mycobacterium smegmatis. European Journal of Biochemistry 180, 587-593.

Stadtman, E. R., Cohen, G. W., Lebras, G. \& de RobichonSZULMAJSTER, M. (1961). Feedback inhibition and repression of aspartokinase activity in E. coli and Saccharomyces cerevisiae. Journal of Biological Chemistry 236, 2033-2038.

Truffa-BaCHI, P. (1973). Aspartokinases. In The Enzymes, 3rd edn, vol 8, pp. 509-553. Edited by P. D. Boyer. New York: Academic Press.
WheELER, P. R. (1984). Metabolism in Mycobacterium leprae: its relation to other research on $M$. leprae and to aspects of metabolism in other mycobacteria and intracellular parasites. International Journal of Leprosy 52, 208-230.

WHEELER, P. R. (1987). Biosynthesis and scavenging of purines by pathogenic mycobacteria including Mycobacterium leprae. Journal of General Microbiology 133, 2999-3011.

WhEELER, P. R. (1989). Pyrimidine scavenging by Mycobacterium leprae. FEMS Microbiology Letters 57, 179-184.

WHEELER, P. R. \& RATLEDGE, C. (1988). Use of carbon sources for lipid biosynthesis in Mycobacterium leprae: a comparison with other pathogenic mycobacteria. Journal of General Microbiology 134, 21112121.

WORLD HEALTh ORganization (1980). UNDP/World Bank/WHO Special Programme for Research and Training in Tropical Diseases. Report of the fifth Meeting on the Immunology of Leprosy (IMMLEP). TDR/IMMLEP-SWG(5)/80.3, Annex 4, p. 23. Geneva: World Health Organization. 